\title{
Beyond Borders and States: Modelling Ocean Connectivity According to Indigenous Cosmovisions
}

\author{
Endalew Lijalem Enyew \\ NCLOS, UiT The Arctic University of Norway
}

\author{
Margherita Paola Poto* \\ Faculty of Law, UiT The Arctic University of Norway
}

Apostolos Tsiouvalas
NCLOS, UiT The Arctic University of Norway

\begin{abstract}
The article describes some common features of Indigenous sea cosmovisions (through examples from Oceania and the Arctic region), from which an understanding of ocean governance rooted in the interconnectedness of all life and the importance of protecting water and people emerges. Hence, the model of ocean (or water) connectivity is characterized by the understanding of ocean-human relationships as a continuum of connections between human and non-human elements. In line with the normative recognition of the sacredness of water, the interconnectedness of all life, and the importance of protecting the sea, Indigenous peoples' law provides insights and implementation solutions for the restoration of marine ecosystems. This study aims to identify blind spots of the current law-of-the-sea regime, where marine ecological connectivity is not fully recognized as a foundational pillar of effective ocean protection. It also suggests approaches towards knowledge integration mechanisms that could minimize critical issues in ocean governance by enabling the enshrinement of Indigenous nature-oriented approaches within the law of the sea regulatory framework (especially focusing on the high seas' regime). The work is structured into three main parts: a comprehensive overview of connectivity conceptualizations drawn from Indigenous cosmovisions; reflections on the model's capability to address law-of-the-sea's systemic challenges; and concluding reflections on possible future trajectories in law-of-the-sea that could encompass elements of the analyzed model.
\end{abstract}

Keywords: ocean connectivity, Oceania, Arctic, marine Indigenous approaches, holistic stewardship, traditional knowledge, LOSC, BBNF, land-sea interface

\footnotetext{
^Correspondence to: Margherita Paola Poto, email: margherita.p.poto@uit.no

(C) 2021 Endalew Lijalem Enyew, Margherita Paola Poto and Apostolos Tsiouvalas. This is an Open Access article distributed under the terms of the Creative Commons CC-BY 4.0 License. eISSN 2387-4562. https://arcticreview.no.

Citation: Endalew Lijalem Enyew, Margherita Paola Poto and Apostolos Tsiouvalas. "Beyond Borders and States: Modelling

Ocean Connectivity According to Indigenous Cosmovisions" Arctic Review on Law and Politics, Vol. 12, 2021, pp. 207-221.

http://dx.doi.org/10.23865/arctic.v12.3290
} 
Responsible Editor: Elise Johansen, NCLOS, UiT The Arctic University of Norway

Received: June 2021; Accepted: September 2021; Published: November 2021

Following the methodology illustrated in the editorial on ocean connectivity (Modelling Ocean Connectivity by Elise Johansen and Margherita Paola Poto, Editorial of this Special Issue), this article explores a model of ocean connectivity developed according to Indigenous cosmovisions. Consistent with the other two models and in response to the research questions and research aims identified in the editorial, the present article is structured into three main sections. Section 1 depicts the model's characteristics (with case studies from Oceania and the Arctic Region); Section 2 investigates how such a model could help address material, epistemic and geopolitical challenges (especially from the viewpoint of ocean justice) that the law of the sea and ocean governance regimes are currently facing. Section 3 assesses how the law of the sea regulatory framework takes into account such a model of connectivity, exploring possible future scenarios for further engagement with Indigenous cosmovisions in ocean governance mechanisms.

\section{Model's Characteristics}

For the purposes of this study, we have identified three main elements of Indigenous conceptualizations of ocean connectivity: connectivity between (1) material and spiritual spaces; (2) temporal stages and seasons, (3) humans and non-humans. In Indigenous orders, there is usually no theoretical abstraction of the separation between human beings and the natural world, and between sea and land. Many coastal Indigenous peoples see and regulate their traditional territories holistically as a sum of continental lands, coastal areas, islands, and traditionally used marine ecosystems, sometimes including waters that underlie sovereignty and jurisdiction of neighboring States. ${ }^{1}$ For marine and coastal Indigenous peoples, "land and sea space are integrated within systems of customary tenure, local knowledge, and resource use and management". ${ }^{2}$ Indigenous stories, value-sets, and beliefs largely converge towards a recognition of the oneness of all things. Literature records that Indigenous cosmovisions often uphold a relationship of respect and symbiosis with human, natural, and supernatural universes. Nature patterns correspond to social and human patterns (cycles of ocean tides, seasons, migrations, sunrise, and sunset). ${ }^{3}$ Such cosmologies help forge systems of socially embedded rules that place the natural world at the center of protection. ${ }^{4}$ The interconnectedness of nature and human beings is a core belief shared by many communities that live in close connection with ecosystems and are traditionally dependent on them: typically, it 
is the elders who are the experts and transmit such cosmovisions through storytelling, examples, and language. ${ }^{5}$

While this vision of land-sea connectivity is widely shared by many marine and coastal Indigenous peoples around the globe, ${ }^{6}$ Indigenous peoples from Oceania (the collective name for the Central and South Pacific Ocean islands) and the Arctic region offer some of the most iconic examples of Indigenous visions rooted in the symbiotic relationship between human beings and the natural environment. Among the marine communities of Oceania, the Indigenous Australians $^{7}$ and the Māori of New Zealand (Aotearoa in the Māori language) stand out for their recognition of the centrality of water (rivers, watercourses, and sea) and land in their lives and the role of coastal communities in protecting them. Similarly, in the Arctic region, the ocean and the sea ice are the nurturing habitat of many Indigenous peoples. ${ }^{8}$

The Aboriginal peoples know Australia as the 'sea country', indicating a sense of an entire cultural and spiritual land-and-seascape relationship. ${ }^{9}$ Thus, their perspectives focus on holistic approaches to human stewardship of nature, challenging Western concepts of land and sea as stocks of resources, rights, and commodities. These people care communally for their 'country', respecting their traditional laws and customs and developing a system of responsibilities to protect them. ${ }^{10}$ Mary Graham asserts that two axioms underpin Aboriginal relations with land and sea: the land-sea is the law, and we are not alone. ${ }^{11}$ Thus, the landsea is sacred, and the basis of any relationship. The relationship between nature and peoples determines all human relationships and is the pattern for social and, therefore, institutional relations. Similarly, referring to the Torres Strait Islanders and their relationship to the sea, Nietschmann describes their views of land-sea continuity as follows:

Sea territories are not just bounded sea space but areas named, known, used, claimed, and sometimes defended ... A territory, whether terrestrial or marine, is more than simply spatially delimited and defended resources for the exclusive use of a particular group. A territory is social and cultural space as much as it is resource or subsistence space. ... Places used are places named. [Indigenous] Peoples conceptually produce the environment they use, delimit and defend. ${ }^{12}$

Similar value-sets are shared by the Māori peoples of New Zealand, who developed a working definition of stewardship, kaitiakitanga, which can be broadly translated as guardianship, preservation, conservation, fostering, protecting, and sheltering. ${ }^{13}$ The guardians of the natural world and its domain are the Papatūanuku (Mother Earth), the Ranginui (Father Sky), and their many children, including Tangaroa (the Oceans). Human beings (ira tangata) play a role as kaitiaki (caretakers) and have an obligation to nurture and protect the physical and spiritual wellbeing of the natural 
systems that surround and support them. ${ }^{14}$ Kaitiaki are agents that perform the task of active guardianship and are charged with the responsibility of safeguarding and managing natural resources for present and future generations. Decisions enacted by the kaitiaki are based on inter-generational observations and experiential understandings. ${ }^{15}$

The Indigenous peoples of the Arctic region, and here we refer specifically to the Inuit, Aleuts, Gwich'in, and Athabaskan peoples, ${ }^{16}$ also embrace the wholeness of their traditional territories, with no distinction between terrestrial areas, fast-ice zones, and marine environments. ${ }^{17}$ They call themselves 'peoples of the land, ice, snow, and sea'. ${ }^{18}$ While there are specific characteristics and differences among the various Indigenous peoples of the Arctic region, most of them share certain common features, including a culture characterized by dependence on subsistence harvesting in both terrestrial and marine environments, sharing of food, travel on snow and ice, a common base of traditional knowledge, and adaptation to similar climatic conditions. ${ }^{19}$ The unique cultures, economy, and identity of the Arctic Indigenous peoples depend upon the continuity of the land and sea; and in this respect, sea ice is crucial and serves as a bridge to such environments. ${ }^{20}$ Marine species traditionally hunted by Indigenous peoples, including polar bears, ice-living seals, walruses, and some marine birds, are dependent on sea ice and breed on the ice. Indigenous peoples also use sea ice to travel to hunting and harvesting grounds as well as for communication between communities residing in different locations. ${ }^{21}$ Thus, it is evident that the connectedness of the land, ice, and marine areas is crucial for the survival and continuity of their unique cultures and ways of life, and for fulfilling the subsistence of many Indigenous communities of the Arctic region.

The Arctic Indigenous peoples' conception of interconnected lands, ice, and seascapes has also served as a means for political mobilization. For example, in 2009, the Inuit Tapiriit Kanatami ${ }^{22}$ organization took spatial framing one step further when it created a new map for Canada's Arctic region entitled "Inuit Nunangat" (Map 1). ${ }^{23}$ Nunangat is a Canadian Inuktitut term that encompasses lands, marine areas, and ice, demonstrating that the Inuit consider the land, water, and ice to be connected and "integral to their culture and way of life". ${ }^{24}$ The map replaced Canada's provincial and territorial boundaries with terraqueous borders based on traditional use and occupancy and raised questions regarding Canada's sovereignty and political jurisdiction within these traditional areas. ${ }^{25}$ If Canada were to conceptualize territory from an Inuit perspective grounded on spatial connectivity, both the geopolitical balance in the region and the ability of LOSC to settle disputes over the Northwest Passage would be drastically challenged. ${ }^{26}$

The transnational conception of culture and traditional ways of life of the Inuit across the Arctic has also led to political claims in the recent case of Pikialasorsuaq (North Water Polynya). Pikialasorsuaq is a polynya that lies between Greenland 


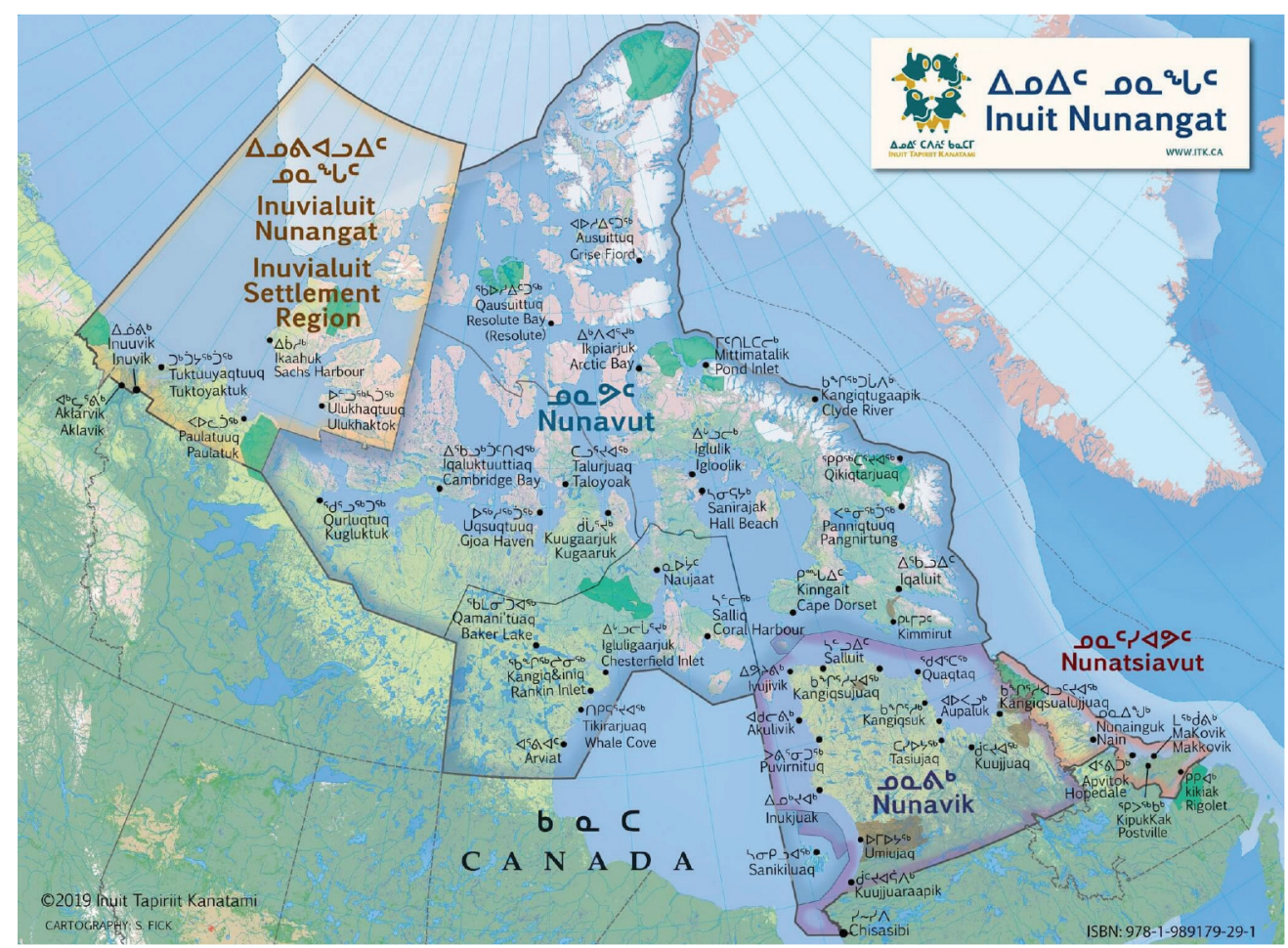

Map 1. Credits to Inuit Tapiriit Kanatami. Inuit Nunangat map. https://www.itk.ca/inuit-nunangatmap/ (accessed May 19, 2021). ${ }^{27}$

and Canada in the northern Baffin Bay, where cross-border subsistence activities between the Inuit of both sides have been carried out for millennia. ${ }^{28}$ The polynya is the most biologically productive region north of the Arctic Circle, provides food security for regional communities on both sides, and remains an enduring spiritual cornerstone linking Inuit from both sides to each other and their shared culture and history. ${ }^{29}$ Although cross-border transportation is nowadays limited by domestic legislation, the Inuit have been striving to maintain and strengthen their distinctive spiritual relationship with their traditional lands, territories, waters and coastal seas, and biodiversity connected with both sides of the polynya. ${ }^{30}$ Thus, in 2017, the Inuit of Greenland and Canada, through the domestic departments of their international representative body Inuit Circumpolar Council (ICC), issued a report requesting the reconstruction of a collective Inuit caretaking regime for the polynya based on their customary cross-jurisdictional connectedness. ${ }^{31}$

As these examples demonstrate, connectivity is inherent in Indigenous peoples' conceptions of land and sea spaces, and is mainly defined in terms of the spatial extent of the communities' spiritual attachment, and traditional occupation or use of those spaces. This understanding, in turn, has a significant implication on the 
rights of Indigenous peoples to marine space. It suggests that the rights of Indigenous peoples to practice their cultures, to own, use and manage their traditional territories and associated resources, as well as to participate in decision-making processes related to those rights are not confined to terrestrial areas, but extend to the sea beyond the maritime boundaries and therefore beyond the law and geopolitics of such boundaries. ${ }^{32}$ Such an understanding has recently been recognized by the different human rights law instruments, ${ }^{33}$ practices of UN treaty monitoring bodies, ${ }^{34}$ and other UN bodies. ${ }^{35}$

\section{Model's Capability to Address the Three Challenges}

Exploring the concept of connectivity embedded in Indigenous legal orders (connectivity between: material and spiritual spaces, temporal stages and seasons, and humans and non-humans) helps address and offers insight into three challenges facing the existing law of the sea and ocean governance regimes: ${ }^{36}$ material (climate change and biodiversity loss), epistemic (fragmentation of the current regulatory framework), and geopolitical (state sovereignty over the sea).

Indigenous views on connectivity emphasize the symbiotic relationship between beings and ecosystems, and strive to maintain a harmonious connection with nature. Such views promote the protection of nature as a response to the challenges posed by climate threats. Legal research focusing on Indigenous knowledge offers several possible remedies to the undisputed anthropocentric origin of climate change, reflected in the legal fabric of international law. We could, thus, seek to counterbalance anthropocentrism by implementing nature-centered visions (climate action that is Indigenous-driven and regulated), Indigenous agreements, Indigenous law, and by prioritizing and reporting the voices of Indigenous representatives. ${ }^{37}$

In response to the epistemic challenges posed by institutional fragmentation, and geopolitical challenges posed by the logic of state sovereignty over the sea, Indigenous cosmovisions could point towards an extraterritorial, ecocentric approach to governance. Indigenous knowledge and law originate in, develop from, and are informed by close observations of nature, and they converge on nature-centric and nature-connected visions. Indigenous laws reflect nature laws and are not subject to the divide created by a detachment, separation, or domination over nature. Conversely, with the LOSC being molded by the State-sovereignty paradigm, the status quo of ocean governance remains, to a great extent, premised upon the logic of objectification and exploitation of nature. ${ }^{38}$ Although under the LOSC the preexisting unrestricted exploitation of marine resources became increasingly qualified by obligations to protect and preserve the marine environment (particularly in part XII of the Convention), the Convention's overall goal to promote economic growth is often prioritized..$^{39}$ Recognizing and embracing Indigenous visions on ocean governance in terms of a polycentric, fluid system of governance, grounded on the value 
of connectivity, has the logical implication of placing the ocean at the center of policy and law, and other actors (as ocean stewards) at the periphery. ${ }^{40}$

\section{LOSC, ongoing developments, and ways forward}

As previously discussed, there is a conceptual division between the dominant Western view ${ }^{41}$ and Indigenous perspectives on ocean space. Unlike Western thinking, which draws a clear distinction between terrestrial and marine areas, ${ }^{42}$ Indigenous worldviews on land and sea "are not terrestrially bound (terra-centric)". ${ }^{43}$ The issue addressed in this section is whether and how international law of the sea considers or disregards ocean connectivity in the context of Indigenous peoples (i.e. the second model of connectivity). ${ }^{44}$

While the LOSC aims to provide a comprehensive legal order for the seas and the oceans by regulating 'all issues relating to the law of the sea', ${ }^{45}$ emerging challenges cast doubt as to whether the Convention is indeed capable of such a task. ${ }^{46}$ One of the main systemic challenges that the law of the sea is currently confronted with relates to problems that spring from the prevailing legal construction of the ocean space. The current law of the sea framework principally distinguishes between land and the sea. This land-sea dichotomy contravenes the holistic vision of Indigenous peoples, and ignores the fact that activities conducted on land may affect the rights of local communities and Indigenous peoples related to their traditional use of marine spaces and resources. ${ }^{47}$ Even though the LOSC considers the land-sea interface in the specific context of marine pollution and provides certain provisions dealing with land-based pollution (Articles 194, $207 \& 213),{ }^{48}$ none of these provisions recognizes the rights (and role) of Indigenous peoples in this context. Moreover, on their own, these provisions are too general and often insufficient to address the problem of land-based pollution and its impacts on Indigenous peoples. ${ }^{49}$

The law of the sea also principally follows a zonal division of the ocean space, where each maritime zone is subject to different levels of State sovereignty and jurisdiction, and governed by distinct regulatory mechanisms. This zonal approach and the associated logic of State sovereignty has various consequences on Indigenous peoples. First, it neglects the 'social construction of the ocean', 50 including Indigenous peoples' views on sea spaces (irrespective of imposed maritime zones) as continuous geographical units (highlighted above). As such, the legal architecture of the ocean has contributed to the continuing marginalization of the deeply embedded relationship that Indigenous peoples have with the sea, and its significance to their cultural identity and spirituality, as well as their traditional laws that govern marine spaces. One exception in this regard is the LOSC's recognition of the continuity of traditional fishing rights (TFRs) within the archipelagic waters of an immediately adjacent neighboring State, according to Articles $47(6)^{51}$ and $51(1) .^{52}$ Similarly, international arbitral tribunals - particularly the Eritrea/Yemen and the South China Sea tribunals - have recognized the continuity of TFRs of artisanal 
fishing communities within the territorial sea of an opposite or adjacent neighboring State, ${ }^{53}$ by broadly interpreting Article 2(3) of the LOSC. ${ }^{54}$ Even though the above provisions of the LOSC and arbitral awards do not expressly reference Indigenous peoples or communities, it is evident that Indigenous peoples are amongst those who benefit from the protections extended to traditional fishing practices. ${ }^{55}$ Thus, we can say that, in these contexts, the LOSC takes into account Indigenous peoples' understandings of ocean connectivity.

The second consequence of the legal categorization of ocean spaces is that the LOSC has not paid adequate attention to the fact that waters in each maritime zone do not exist in isolation. These waters are ecologically connected in the sense that ocean currents, movements of migratory species, and shipping activities, among other factors, inter-connect different marine ecosystems. ${ }^{56}$ Ecological connectivity between marine ecosystems means that negative impacts - such as overfishing and pollution - within $\mathrm{ABNJ}$ can affect marine species in coastal waters (waters under the national jurisdiction of coastal States generally) traditionally occupied or used by Indigenous peoples. ${ }^{57}$ Thus, the LOSC's disregard of Indigenous views on connectivity makes it difficult to take adequate regulatory measures to curb negative impacts that arise from ecological connectivity.

In short, the LOSC does not expressly embrace Indigenous peoples' views on connectivity with the exception of provisions dealing with TFRs, which have been interpreted to apply to Indigenous peoples. The LOSC also fails to offer adequate mechanisms to address the challenges that ecological ocean connectivity (including land-sea interface) may pose to Indigenous peoples. Indeed, the current spatial architecture of ocean space constructed by the LOSC tends to exacerbate the risks that ecological ocean connectivity may pose on the lives and rights of Indigenous peoples.

Although the LOSC does not yet expressly acknowledge that the spiritual relationship of coastal Indigenous communities to marine areas often extends across national jurisdictions, international soft law documents provide fertile ground for an operationalization of such an understanding within state policies. For instance, FAO's Voluntary Guidelines for Securing Sustainable Small-Scale Fisheries in the Context of Food Security and Poverty Eradication (SSF Guidelines) provide that the knowledge, culture, traditions, and practices of small-scale fishing communities (including Indigenous peoples) should be recognized and supported as an integral part of sustainable development (para 11.6), while states should recognize the importance of coordinating the migration of fishers and fish workers in smallscale fisheries across national borders (para 6.10). ${ }^{58}$ Similarly, the 2012 Voluntary Guidelines on the Responsible Governance of Tenure of Land, Fisheries, and Forests in the Context of National Food Security acknowledge that land, fisheries, and forests have, amongst others, spiritual value to Indigenous peoples and other communities with customary tenure systems (para 9.1), and call for effective administration of the cross-jurisdictional tenure rights of these communities (para 22.3). ${ }^{59}$ International law-making in light of these guidelines could operationalize 
an Indigenous-centric paradigm and ensure its incorporation within the text of forthcoming agreements.

Despite the gaps in the LOSC highlighted above, current negotiations on a treaty on marine biodiversity in $\mathrm{ABNJ}$ (one of the future trajectories of the international law of the sea $)^{60}$ seem to be heading in the direction of including in its ontology, ocean governance elements of the Indigenous model of connectivity, and more precisely, the narrative of ocean rights, and of an ocean-centric model where human communities act as stewards and custodians. Two possible scenarios can be predicted for the future of the law of the sea. The negotiations will either take into account some characteristics of the model and therefore include elements of an Indigenous definition of ocean connectivity, or an Indigenous approach in combination with a Western approach will contribute to a new integrated approach to ocean governance challenges, as well as find application in other nature-centered governance contexts and, more broadly, improve connectivity, alignment, and collaboration within and between the different legal orders. The problems that derive from the land-sea dichotomy and the legal delineation of ocean space require supplementary and alternative approaches that view land and the different maritime zones together - a view consistent with Indigenous peoples' holistic perception of space. ${ }^{61}$ Indeed, this was one of the contentious issues raised in the previous BBNJ negotiations. Developing and least developed States, who depend heavily on marine resources, argue that the forthcoming BBNJ agreement must include provisions to ensure that all conservation and management measures in ABNJ are informed by their potential impacts on the rights and interests of developing coastal States and Indigenous peoples within these States' coastal waters. ${ }^{62}$ The upcoming BBNJ negotiation, and the final treaty, should address such concerns.

The BBNJ negotiations have also given rise to discussions on the need to promote a model of centrality of the oceans and human and non-human interconnectedness - rather than resting upon humanity's domination over the sea. Along these lines, experts predict four positive outcomes. ${ }^{63}$ First, the BBNJ will be qualified as a right-bearer entity, and not as a resource to be exploited. Second, connectivity will strengthen the current weak coordination between the different elements of the BBNJ's package deal, which addresses marine genetic resources, area-based management tools, environmental impact assessment, and capacity-building in a disconnected way. ${ }^{64}$ In particular, an explicit reference to the diverse corpus of legal provisions focusing on nature-centred visions (e.g. with an express reference to the cosmovisions of the Indigenous peoples of Oceania and the Arctic, among others), and recognizing the key role played by Indigenous knowledge in ocean protection, would help restore both nature and Indigenous rights. Such a restoration is seen as a response to the material, epistemic, and geopolitical challenges that ocean governance is currently facing.

As for material challenges, applying connectivity to BBNJ could help inform the package deal in terms of ecological connectivity, placing the ocean at the center, and 


\section{Endalew Lijalem Enyew, Margherita Paola Poto and Apostolos Tsiouvalas}

implementing and enforcing present and new mechanisms, such as the stewardship of states and other 'nature defenders'.

As for epistemic and geopolitical challenges, the knitting of legal constructs from Western and non-Western legal orders has the potential to translate into effective solutions of cooperation at an institutional level. Starting from the Preamble, affirmation of States as the only stewards of the oceans should be integrated with the intention of establishing a board of stewards or custodians, a board therefore that would acknowledge and include existing mechanisms of protection. Here again, it would be advisable to take into account and integrate Indigenous visions of ocean connectivity (such as the ones illustrated in our case studies), to live up to the aim of achieving "universal participation", expressed in the Preamble of the draft agreement on BBNJ.

All in all, thinking in terms of model integration and model inter-connectivity has paramount benefits, which includes the assignment of the role of ocean stewards to nature defenders (Indigenous peoples among others), ${ }^{65}$ and the integration of divergent legal orders (Western and Indigenous) within one interconnected fabric. Such a legal fabric, rooted in common values (rights, connectivity, reciprocity, and representation), can inform a new ontology of ocean governance where connectivity, alignment, and cooperation may comprise its foundational pillars.

\section{Final Remarks}

In conclusion, at present the existing law of the sea and ocean governance apparatus largely disregards Indigenous models of ocean connectivity. However, some soft law instruments and the ongoing BBNJ negotiations seem to keep Indigenous conceptions of connectivity under their purview. The issue of whether or not a future BBNJ treaty will expressly include Indigenous models of connectivity remains to be seen. We believe that expressing recognition of Indigenous models of ocean connectivity has broader significance in recognizing and protecting Indigenous peoples' rights, which in turn, has potential benefits for legal connectivity in ocean governance. An inclusive approach that views the law of the sea in light of international human rights law and practices of human rights bodies, and which recognizes and encompasses Indigenous peoples' holistic views pertinent to the marine space, would also help to fill the regulatory gap. ${ }^{66}$

\section{Acknowledgments}

The project on Ocean Connectivity is funded by the NCLOS, UiT The Arctic University of Norway. The authors express their gratitude to the anonymous peer reviewers for their comments and insights and to Jess Fowlie, Canada, for the linguistic revision of the manuscript. 


\section{NOTES}

1. Ian Barber, "Sea, Land and Fish: Spatial Relationships and the Archeology of South Island Maori Fishing," World Archaeology 35, no. 3 (2004): 434; Patrick Sullivan. "Salt Water, Fresh Water, and Yawuru Social Organization," in Customary Marine Tenure in Australia, eds. Nicolas Peterson and Bruce Rigsby (Sydney: University Press, 2014) 159-180; National Oceans Office et al., Sea Country - An Indigenous Perspective: The Southeast Regional Marine Plan (Australia: Commonwealth of the Government of Australia, 2002), 2-3.

2. Colin Scott and Monica Mulrennan, "Land and Sea Tenure at Erub, Torres Strait: Property, Sovereignty and the Adjudication of Cultural Continuity," Oceania 70, no. 1 (2015): 146. See also Valmaine Toki. Study on the Relationship between Indigenous Peoples and the Pacific Ocean. Report to Permanent Forum on Indigenous Issues, UN Doc E/C.19/2016/3 (2016).

3. Melissa Nursey-Bray, "Which way? The contribution of Indigenous marine governance," Australian fournal of Maritime and Ocean Affairs 6, no. 1 (2014): 27-40.

4. Ibid.

5. Gregory A. Cajete, Native Science: Natural Laws of Interdependence (NM Santa Fe: Clear Light Publishers, 1999).

6. For a recent study of Indigenous peoples' perceptions of marine space in various national jurisdictions, see Stephen Allen, Nigel Bankes and Oyvind Ravna (eds), The Rights of Indigenous Peoples in Marine Areas (Oxford: Hart Publishing, 2019).

7. According to the definition of the Australian Government "Indigenous Australians" include peoples who: "are of Aboriginal or Torres Strait Islander descent; identify as being of Aboriginal or Torres Strait Islander origin; and are accepted as such in the communities in which they live or have lived. In most data collections, a person is considered to be Indigenous if they identified themselves, or were identified by another household member, as being of Aboriginal or Torres Strait Islander origin. For a few data collections, information on acceptance of a person as being Indigenous by an Indigenous community may also be required." See "Profile of Indigenous Australians," Australian Institute of Health and Welfare, accessed May 13, 2021, https://www.aihw.gov.au/reports/australias-welfare/profile-of-Indigenous-australians.

8. See UN Chronicle: https://www.un.org/en/chronicle/article/arctic-ocean-and-sea-ice-ournuna accessed September 4, 2021.

9. Dermot Smyth and Smyth and Bahrdt Consultants, Indigenous land and sea management: a case study. (Canberra: Department of Sustainability, Environment, Water, Populations and Communities, 2011).

10. Ibid.

11. Mary Graham, "Some thoughts about the philosophical underpinnings of Aboriginal worldviews," Worldviezus: Global Religions, Culture and Ecology 3, no. 2 (1999).

12. Bernard Nietschmann. "Traditional Sea Territories, Resources and Rights in Torres Strait," in $A$ Sea of Small Boats, ed. John Cordell (Cambridge: Cultural Survival Inc. 1989), 60 (emphasis added).

13. Te A. C. Royal, The Woven Universe: Selected Writings of Rev. Māori Marsden (Otaki: Royal Society Te Apārangi and Ngā Pae o te Māramatanga, 2003).

14. Kura Paul-Burke and Lesley Rameka. "Kaitiakitanga active guardianship, responsibilities and relationships with the world: towards a bio-cultural future in early childhood education," in Encyclopedia of Educational Philosophy and Theory, ed. Michael Peters (Singapore: Springer Science and Business Media, 2015).

15. Ibid.

16. Each of these Indigenous peoples resides within the national borders of two or more Arctic States. The Inuit peoples live within the territories of four Arctic States - northern and western Alaska in the United States, northern Canada, Chukotka in the Russian Federation, and 


\section{Endalew Lijalem Enyew, Margherita Paola Poto and Apostolos Tsiouvalas}

Greenland (Kingdom of Denmark). While Aleuts reside in Russia and Alaska, the Gwich'in live in Canada and Alaska. Similarly, the Athabaskan peoples reside within the Arctic regions of Canada (within the territories of Yukon, Northwest Territories, Northern British Columbia, Alberta, Saskatchewan, and Manitoba) and the United States (Alaska). International organizations representing these peoples have Permanent Participant status in the Arctic Council. Our analysis does not specifically focus on other Arctic peoples, such as the Sámi people of Sápmi (the Indigenous region extending across parts of the nation states Finland, Norway, Russia and Sweden), whose livelihood is also very dependent on the Arctic coasts and territories.

17. Nigel Bankes. "Modern Land Claims Agreements in Canada and Indigenous Rights with Respect to Marine Areas and Resources," in The Rights of Indigenous Peoples in Marine Areas, eds. Stephen Allen, Nigel Bankes and Øyvind Ravna (Oxford: Hart Publishing, 2019), 149172; "Inuit: Sea and Land," Virtual Museum Canada, accessed May 13, 2021, http://www. virtualmuseum.ca/edu/ViewLoitLo.do;jsessionid=07077CAEB243CEE84BBFFE54D01EF900?method=preview\&lang=EN\&id=10802.

18. Mark Nutall et al., "Hunting, Herding, Fishing, and Gathering: Indigenous Peoples and Renewable Resource Use in the Arctic," in Arctic Climate Impact Assessment, eds. Carolyn Symon, Lelani Arris and Bill Heal, (Cambridge: University Press, 2004), 649; Sheila Watt-Cloutier, "The Climate Change Petition by the Inuit Circumpolar Conference to the Inter-American Commission on Human Rights," 11th Conference of Parties to the UN Framework Convention on Climate Change, (Montreal, December 7, 2005).

19. See Ekaterina Zmyvalova and Ruslan Garipov. "The Rights of Indigenous Peoples in Marine Areas in Russia," in The Rights of Indigenous Peoples in Marine Areas, eds. Stephen Allen, Nigel Bankes and Øyvind Ravna (Oxford: Hart Publishing, 2019), 271-290; Caskey Russell and X'unei L. Twitchell. "Tlingit Use of Marine Space: Putting up Fish," in The Rights of Indigenous Peoples in Marine Areas, eds. Stephen Allen, Nigel Bankes and Øyvind Ravna (Oxford: Hart Publishing, 2019); Natalia Loukacheva, "Indigenous Inuit Law, "Western" Law and Northern Issues," Arctic Review on Law and Politics 3, no. 2. (2012): 200-2017.

20. Claudio Aporta, "Inuit Orienting: Travelling Along Familiar Horizons," Sensory Studies, accessed November, 2020, https://www.sensorystudies.org/inuit-orienting-traveling-alongfamiliar-horizons/.

21. Scott Heyes, Inuit Knowledge and Perceptions of Land-Water Interface, (PhD diss., McGill University, 2007); Inuit Circumpolar Council, The Sea Ice is Our Highway: An Inuit Perspective on Transportation in the Arctic - A Contribution to Arctic Marine Shipping Assessment (Ottawa: ICC, 2008).

22. Inuit Tapiriit Kanatami is a nonprofit organization in Canada that represents over 65,000 Inuit and "serves as a national voice protecting and advancing the rights and interests of Inuit in Canada"; "We Are The NationalVoice Of Canada’s 65,000 Inuit," Inuit Tapiriit Kanatami, accessed May 13, 2021, https://www.itk.ca/national-voice-for-communities-in-the-canadian-arctic/.

23. “Inuit Nunangat Map," Inuit Tapiriit Kanatami, accessed May 13, 2021, https://www.itk.ca/ inuit-nunangat-map/.

24. The term Inuit Nunangat was introduced in 2009 to replace the previously used term Inuit Nunaat. While the former term describes land but does not include water or ice, the term Inuit Nunangat was adopted as more inclusive and appropriate, encompassing water, land, and ice; see "Maps Of Inuit Nunangat (Inuit Regions Of Canada)," Inuit Tapiriit Kanatami, accessed May 13, 2021, 2020, https://www.itk.ca/maps-of-inuit-nunangat/.

25. Nadine C. Fabbi, Inuit Nunaat as an Emerging Region in Area Studies: Building an Arctic Studies Program South of the Tree Line, (PhD diss., The University of British Columbia, 2015), 68-70.

26. Ibid. 
27. The map Inuit Nunangat was created by Inuit Tapiriit Kanatami and demonstrates the interconnectedness of land-sea-ice as seen by the Inuit.

28. Pikialasorsuaq Commission, People of the Ice Bridge: The Future of the Pikialasorsuaq, Report of the Pikialasorsuaq Commission (Ottawa: ICC, 2017) A-19.

29. Ibid, A-9.

30. Ibid, A-6.

31. Ibid, XII; for a more comprehensive discussion over the Pikialasorsuaq case, see Apostolos Tsiouvalas, "Potentials for the Protection of Pikialasorsuaq in the Shadow of Contemporary Maritime Industries," Facta Universitatis: Law and Politics 17, no. 1 (2019): 23-32.

32. See Endalew L. Enyew, The Rights of Indigenous Peoples to Marine Space and Marine Resources Under International Law, (PhD diss., UiT-The Arctic University of Norway, 2019), ch 4.

33. In particular, see International Labour Organization (ILO), Indigenous and Tribal Peoples Convention, C169, 1989, Art 13(2); United Nations General Assembly, United Nations Declaration on the Rights of Indigenous Peoples, 2007, Art 25.

34. See for example, HRC, Apirana Mahuika et al v New Zealand, Communication No 547/1993, UN Doc CCPR/C/70/D/547/1993 (27 October 2000); CERD Committee, New Zealand Foreshore and Seabed Act 2004: Decision 1(66), UN Doc CERD/C/DEC/ NZL/1 (27 April 2005) [6-8]; HRC, Concluding Observations on the Seventh Periodic Report of Norway, UN Doc CCPR/C/NOR/CO/7 (25 April 2018) [36]; CERD Committee, Concluding Observations on the Combined Twenty-third and Twenty-fourth Periodic Reports of Norway, UN Doc CERD/C/NOR/CO/23-24 (2 January 2019), [21(d) \& 22(e)]; CERD Committee, Concluding Observations on the Combined Twenty-first and Twenty-second Periodic Reports of Norway, UN Doc CERD/C/NOR/CO/21-22 (25 September 2015), [29 (d) and 30 (b) \& (f)]; CERD Committee, Concluding Observations on the Combined Twentieth and Twenty-First Periodic Reports of France, UN Doc CERD/C/FRA/CO/20-21 (10 June 2015), [13]. For a detailed discussion, see Endalew L. Enyew. "International Human Rights Law and the Rights of Indigenous Peoples in Relation to Marine Space and Marine Resources," in The Rights of Indigenous Peoples in Marine Areas, eds. Stephen Allen, Nigel Bankes and Øyvind Ravna (Oxford: Hart Publishing, 2019), 45-68.

35. Valmaine Toki (Special Rapporteur), 'Study on the Relationship between Indigenous Peoples and the Pacific Ocean', Report to Permanent Forum on Indigenous Issues, UN Doc E/C.19/2016/3 (2016); Carsten Smith and Michael Dodson (Special Rapporteurs), "Report on Indigenous Fishing Rights in the Seas with Case Studies from Australia and Norway," Permanent Forum on Indigenous Issues, UN Doc E/C.19/2010/2 (2010).

36. For further details see Modelling Ocean Connectivity by Elise Johansen and Margherita Paola Poto, editorial of this Special Issue.

37. Margherita P. Poto and Endalew L Enyew. "Nature Protection, Indigenous Rights, and Climate Action," in Klimarett, ed. Hans Christian Bugge (Oslo: Universitetsforlaget, 2021) forthcoming.

38. Pierre Cloutier de Repentigny, "To the Anthropocene and beyond: the responsibility of law in decimating and protecting marine life," Transnational Legal Theory 11 no. (1-2) (2020): 181.

39. Ibid.

40. Margherita P. Poto. "Thinking About Ocean Governance: by whom, for whom?," in Vol. on $A B N \mathcal{~ , ~ S e r i e s : ~ P u b l i c a t i o n s ~ o n ~ O c e a n ~ D e v e l o p m e n t s , ~ e d s . ~ V i t o ~ d e ~ L u c i a , ~ A l e x ~ O . ~ E l f e r i n k ~ a n d ~}$ Lan N. Nguyen (Leiden: Brill, 2022) forthcoming.

41. Here the term 'Western' is used as a synonym for 'Eurocentric', and juxtaposed with 'Indigenous' and 'non Western', following the strands of decolonial scholarship. See in this sense: Melody Fonseca "Global IR and western dominance: moving forward or Eurocentric entrapment?," Millennium 48, no. 1 (2019): 45-59. 


\section{Endalew Lijalem Enyew, Margherita Paola Poto and Apostolos Tsiouvalas}

42. Stephen Allen et al. "Introduction" in The Rights of Indigenous Peoples in Marine Areas, eds. Stephen Allen, Nigel Bankes and Øyvind Ravna (Oxford: Hart Publishing, 2019), 1-14, 2; Sue E. Jackson, "The Water is not Empty: Cross-cultural Issues in Conceptualizing Sea Space," Australian Geographer 26, no. 1 (1995): 87, 89.

43. Sue Jackson, "The Water is not Empty: Cross-cultural Issues in Conceptualizing Sea Space," Australian Geographer 26, no.1 (1995): 94.

44. For a discussion of Models 1 and 3, see articles 1 and 3 respectively of this special issue.

45. United Nations Convention on the Law of the Sea, LOSC, (Montego Bay 10 December 1982, in force 16 November 1994) 1833 UN Treaty Series, 3, preamble, recital 1.

46. See Richard Barnes. "The Continuing Vitality of LOSC" in Law of the Sea: LOSC as a Living Treaty, eds. Jill Barrett and Richard Barnes (London: BIICL, 2016); and Jill Barrett. "The UN Convention on the Law of the Sea: A Living Treaty," in Law of the Sea: LOSC as a Living Treaty, eds. Jill Barrett and Richard Barnes (London: BIICL, 2016).

47. One case currently under controversy is Norway's approval of a mining company (Nussir ASA) to extract copper from beneath a mountain plateau in Kvalsund municipality in Troms and Finnmark county, and dump its waste (tailings) into the Repparfjord on the Barents Sea coast - a protected national salmon fjord and rich fishing fjord traditionally used by the Sea Sámi. The Sámi people opposed to the permit argue that the dumping of waste will destroy their fisheries and traditional livelihoods, see "Repparfjord/Nussir Copper Mining Case Norway," Environmental Justice Atlas, accessed May 14, 2021, https:/ejatlas.org/conflict/reppardfjord-nussir-case; Apostolos Tsiouvalas. "Submarine Tailings Disposal in Arctic Indigenous Waters: A Human Rights Perspective on Nussir Mine's Impacts on the Sámi Use of Repparfjord, Norway," in Struggles for Recognition: Cultural Diversity and Rights of Minorities, eds. Oscar Perez de la Fuente, Monique Falcão and J. Daniel Oliva Martínez (Madrid: Dykinson, S. L., 2021), 357-374.

48. See also the discussion of this issue under model 1 (biology-centric model of connectivity) in the context of ocean acidification.

49. See Linda Finska and Julie G Howden, "Troubled Waters - Where is the Bridge? Confronting Marine Plastic Pollution from International Watercourses," RECIEL 27, no.1 (2018): 204; Anne M. O’Hagan, Shona Paterson and Martin Le Tissier, "Addressing the Tangled Web of Governance Mechanisms for Land-sea Interactions: Assessing Implementation Challenges Across Scales," Marine Policy 112, no. 1 (2020).

50. Philip E. Steinberg, The Social Construction of the Ocean (Cambridge: University Press, 2001).

51. Art 47(6) stipulates as follows: 'If a part of the archipelagic waters of an archipelagic State lies between two parts of an immediately adjacent neighboring State, existing rights and all other legitimate interests which the latter State has traditionally exercised in such waters and all rights stipulated by agreement between those States shall continue and be respected' (emphasis added).

52. Article 51(1) provides that: 'Without prejudice to article 49, an archipelagic State shall respect existing agreements with other States and shall recognize traditional fishing rights and other legitimate activities of the immediately adjacent neighboring States in certain areas falling within archipelagic waters' (emphasis added).

53. See Arbitration between the Government of the State of Eritrea and the Government of the Republic of Yemen, Award of the Arbitral Tribunal in the First Stage of the Proceedings (Territorial Sovereignty and Scope of the Dispute), London (9 October 1998); Arbitration between the Government of the State of Eritrea and the Government of the Republic of Yemen, Award of the Arbitral Tribunal in the Second Stage of the Proceedings (Maritime Delimitation), London (17 December 1999).

54. Article 2(3) of the LOSC provides that: 'The sovereignty over the territorial sea is exercised subject to this Convention and to other rules of international law'. For interpretation of Art 
2(3) to embrace TFRs, see South China Sea Arbitration (The Republic of the Philippines v The People's Republic of China), Arbitral Tribunal Constituted under Annex VII of the 1982 United Nations Convention on the Law of the Sea, PCA, Award on the Merits (12 July 2016), paras 554-812.

55. For a detailed discussion, see Endalew L. Enyew, The Rights of Indigenous Peoples to Marine Space and Marine Resources Under International Law, (PhD diss., UiT-The Arctic University of Norway, 2019).

56. Ekaterina Popova et al., "So Far, Yet So Close: Ecological Connectivity between ABNJ and Territorial Waters," IIED Briefing (2019). See also the first model of connectivity discussed above.

57. Ekaterina Popova et al., "Ecological Connectivity between the Areas Beyond National Jurisdiction and Coastal Waters: Safeguarding Interests of Coastal Communities in Developing Countries," Marine Policy 104 (2019): 90; Daniel C. Dunn et al., “Adjacency: How Legal Precedent, Ecological Connectivity, and Traditional Knowledge Inform Our Understanding of Proximity," Nereus Scientific and Technical Briefs on ABNf Series.

58. Food and Agriculture Organization of the United Nations, Voluntary Guidelines for Securing Sustainable Small-Scale Fisheries in the Context of Food Security and Poverty Eradication (Rome: FAO, 2015).

59. Food and Agriculture Organization of the United Nations, Voluntary Guidelines on the Responsible Governance of Tenure of Land, Fisheries and Forests in the Context of National Food Security (Rome: FAO, 2012).

60. See text proposals submitted by delegations by 20 February 2020, for consideration at the fourth session of the Intergovernmental conference on an international legally binding instrument under the United Nations Convention on the Law of the Sea on the conservation and sustainable use of marine biological diversity of areas beyond national jurisdiction (the Conference), in response to the invitation by the President of the Conference in her Note of 18 November 2019 (A/CONF.232/2020/3); Vito De Lucia, "Ocean Commons, Law of the Sea and Rights for the Sea," Canadian fournal of Law and Furisprudence 32, no. 1 (2019): 45.

61. See for example, KristofVan Assche et al., "Governance and the Coastal Condition:Towards New Modes of Observation, Adaptation and Integration," Marine Policy 112, no.1 (2020); Achim Schlüter et al, "Land-sea Interactions and Coastal Development: An Evolutionary Governance Perspective," Marine Policy 112, no. 1 (2020); Ramachandran Ramesh et al., "Land-ocean Interactions in the Coastal Zone: Past, Present and Future," Anthropocene 12, no. 1 (2015): 85.

62. Popova et al., "So Far, Yet So Close: Ecological Connectivity between ABNJ and Territorial Waters".

63. Harriet Harden-Davies, Fran Humphries, Michelle Maloney, Glen Wright, Kristina Gjerde, and Marjo Vierros (2020). "Rights of Nature: Perspectives for Global Ocean Stewardship," Marine Policy 2020:7.

64. Ibid.

65. For an in-depth analysis of ocean rights in the context of Marine Protected Areas see the Report of the Earth Law Center: https://static1.squarespace.com/static/55914fd1e $4 \mathrm{~b} 01 \mathrm{fb}-$ Ob851a814/t/5adca14b352f538288f4ea67/1524408668126/Final+Draft+3.pdf, Accessed May 14, 2021.

66. See Endalew L. Enyew and Nigel Bankes. "Interaction between the Law of the Sea and the Rights of Indigenous Peoples," in The Law of the Sea: Normative Context and Interactions with Other Legal Regimes, eds. Nele Matz-Luck, Øystein Jensen and Elise Johansen (Routledge Publishing, 2021), forthcoming. 